\title{
Ecological and technological effects of using concretes with low Portland clinker
}

\author{
Mikołaj Ostrowski ${ }^{1, *}$, Pawet Pichniarczyk ${ }^{2}$, and Grzegorz Kądzielawski ${ }^{3}$ \\ ${ }^{1}$ Sieć Badawcza Łukasiewicz - ICIMB Kraków \\ ${ }^{2}$ Sieć Badawcza Łukasiewicz - ICIMB Warszawa \\ ${ }^{3}$ Akademia WSB - Dąbrowa Górnicza
}

\begin{abstract}
Concrete with a low Portland clinker content involves the use of mineral additives as a cement component or as a additive in a concrete mix. The main factors influencing the increasing use of mineral additives in concrete technology are the advantageous development of the functional properties of the concrete mix, hardened concrete and a large impact on the ecological effects, including reduction of $\mathrm{CO}_{2}$ emissions. The use of concrete with a low Portland clinker content is part of the strategy for sustainable development of the economy. This paper describes the technological and ecological effects of using silica fly ash and granulated blast furnace slag additives in concretes with a low Portland clinker content. The cement and concrete additives used were mechanically activated, which allowed to reduce the content of Portland clinker in concrete. A new generation superplasticizer was used in the research, enabling a low water-cement ratio to be obtained. The mechanical properties and ecological effects of the production and use of concretes with a low content of Portland clinker were determined, including the reduction of $\mathrm{CO}_{2}$ emissions. Test results confirmed the very good mechanical properties of concrete with a high content of mechanically activated mineral additives. The research also showed an average of 3 times lower $\mathrm{CO}_{2}$ emissions compared to reference concretes made of CEM I Portland cement without additives.
\end{abstract}

\section{Introduction}

Granulated blast furnace slag and silica fly ash have long been widely used as active ingredients that can significantly modify the properties of both concrete mix and hardened concrete [1-4]. With the development of technological processes in the production of cement and concrete, the use of these additives is more effectively and allows the production of high strength and durability concrete [5-7].

\footnotetext{
*Corresponding author: m.ostrowski@icimb.pl
} 
The impact of mineral additives on the properties of the concrete mix and hardened concrete is determined by the hydraulic properties of granulated slag and/or the pozzolanic properties of silica fly ashes, which can be introduced as a Type II additives to concrete or with multi-component cements. Most publications about the activity of granulated slag and fly ash in the processes of hardening cement binders, associate these hydraulic and/or pozzolanic properties with their chemical composition and glass phase content $[3,4,8,11]$.

If the chemical composition of these additives is correct, the glassy phase content is a determining factor for the activity of granulated blast furnace slag and siliceous fly ash. Polish resources of fly ashes and slags are characterized by chemical composition and glassy phase content that guarantee their good activity. The degree of glass transition of granulated blast furnace slag exceeds $90 \%$, and the content of the glassy phase in silica fly ash is $60 \div 80 \%$ [9-10].

The connections between the potential activity of blast furnace slag, fly ash and their chemical composition and glassy phase content are also determined by the degree of slag and fly ash fineness. The increase fineness of granulated slag leads to an improvement of activity. Modern milling cement technologies are more effective then oldest grinding methods and it is not problem to effectively grind a slag cement to high specific surfaces. In the case of multi-component ash cements better properties of cement are related with high fineness of fly ash, what we can get by the dynamic separation method [4, 11-14].

With a very high degree of slag fineness and fly ash fineness, these materials can be very active additives and also perform a function similar to the role of reactive powders in modern concrete composite technologies $[15,16]$. The use of ultra-fine grains of ground granulated blast furnace slag and silica fly ash as active additives for concrete allows shape a cement matrix with high strength properties [16, 17]. This effect can be caused by mechanical activation of the analyzed additives by increasing the fineness of granulated blast furnace slag by effective grinding method and dynamic separation of fine fractions of fly ash with particle size $\mathrm{D}_{50}<10 \mu \mathrm{m}$. Taking into account the activation methods described in this paper, the authors assumed objective to design and production concrete with compressive strength up to $100 \mathrm{MPa}$ while the maximum reduction of the Portland clinker content- below $100 \mathrm{~kg} / \mathrm{m}^{3}$. In the next phase of research, authors assumes that positive results of mechanical properties must be related with tests of concrete performance. They should meet the requirements of durability properties of ordinary and special concretes, designed and manufactured for specific exposure classes, as defined in PN-EN 206 [18].

\section{Materials and Methods}

Concretes with a reduced Portland clinker content were made of CEM III / B 42.5L-LH / SR-NA, industrially produced by the method of joint mixing of components. The content of ground to high specific surface granulated blast furnace slag in cement was $70 \%$. The specific surface area of cement was $5000 \mathrm{~cm}^{2} / \mathrm{g}$ (Tab. 1). The obtained test results were referred to control concrete made of CEM I 42.5 R (Tab. 1).

Table 1. Chemical composition of cements used in research [19].

\begin{tabular}{|l|c|c|c|c|c|c|c|c|c|c|}
\hline \multirow{3}{*}{ Material } & \multicolumn{7}{|c|}{ Ingredients content [\% of mass] } \\
\cline { 2 - 11 } & $\mathrm{LOI}$ & $\mathrm{SiO}_{2}$ & $\mathrm{Al}_{2} \mathrm{O}_{3}$ & $\mathrm{Fe}_{2} \mathrm{O}_{3}$ & $\mathrm{CaO}$ & $\mathrm{MgO}$ & $\mathrm{SO}_{3}$ & $\mathrm{Na}_{2} \mathrm{O}$ & $\mathrm{K}_{2} \mathrm{O}$ & $\mathrm{Na}_{2} \mathrm{O}_{\text {eq* }}$ \\
\hline CEM I 42,5R & 2.92 & 19.65 & 5.14 & 2.46 & 63.89 & 1.27 & 2.94 & 0.11 & 0.77 & 0.62 \\
\hline $\begin{array}{l}\text { CEM III/B 42,5 } \\
\text { L-LH/SR-NA }\end{array}$ & 0.78 & 33.07 & 6.68 & 1.62 & 51.52 & 2.80 & 2.41 & 0.41 & 0.58 & 0.79 \\
\hline
\end{tabular}

$* \mathrm{Na}_{2} \mathrm{O}_{\text {eq }}=\% \mathrm{Na}_{2} \mathrm{O}+0,658 . \% \mathrm{~K}_{2} \mathrm{O}$ 
As a type II additive in concrete, silica fly ash category $\mathrm{N}$ and category $\mathrm{S}$ were used.

Category S fly ash was obtained as a result of mechanical activation consisting in the dynamic separation of a fine fraction from category $\mathrm{N}$ fly ash (Tab. 2). Changes in fly ash graining after the activation process are given in Figure 1. The improvement of fly ash fineness from $37.4 \%$ (for category $\mathrm{N}$ ) to $2.8 \%$ (for category $\mathrm{S}$ ) ensures a significant reduction in the $\mathrm{D}_{50}$ value from $40.9 \mu \mathrm{m}$ to $7.7 \mathrm{um}$. The effect of mechanical activation of ash, due to grain morphology and fineness, is very well illustrated by SEM photographs of fly ash $\mathrm{N}$ and $\mathrm{S}$ in Figure 2. Most of the fly ash $\mathrm{S}$ grains are spherical forms of small dimensions.

Table 2. Chemical composition of silica fly ash used in research.

\begin{tabular}{|c|c|c|c|c|c|c|c|c|c|c|}
\hline \multirow{2}{*}{ Material } & \multicolumn{10}{|c|}{ Ingredients content [\% of mass] } \\
\cline { 2 - 10 } & $\mathrm{LOI}$ & $\mathrm{NR}$ & $\mathrm{SiO}_{2}$ & $\mathrm{Al}_{2} \mathrm{O}_{3}$ & $\mathrm{Fe}_{2} \mathrm{O}_{3}$ & $\mathrm{CaO}$ & $\mathrm{MgO}$ & $\mathrm{SO}_{3}$ & $\mathrm{Na}_{2} \mathrm{O}$ & $\mathrm{K}_{2} \mathrm{O}$ \\
\hline $\begin{array}{c}\text { Siliceous } \\
\text { fly ash }\end{array}$ & 2.63 & 79.8 & 51.37 & 27.80 & 6.55 & 2.97 & 2.51 & 0.23 & 0.68 & 3.54 \\
\hline
\end{tabular}

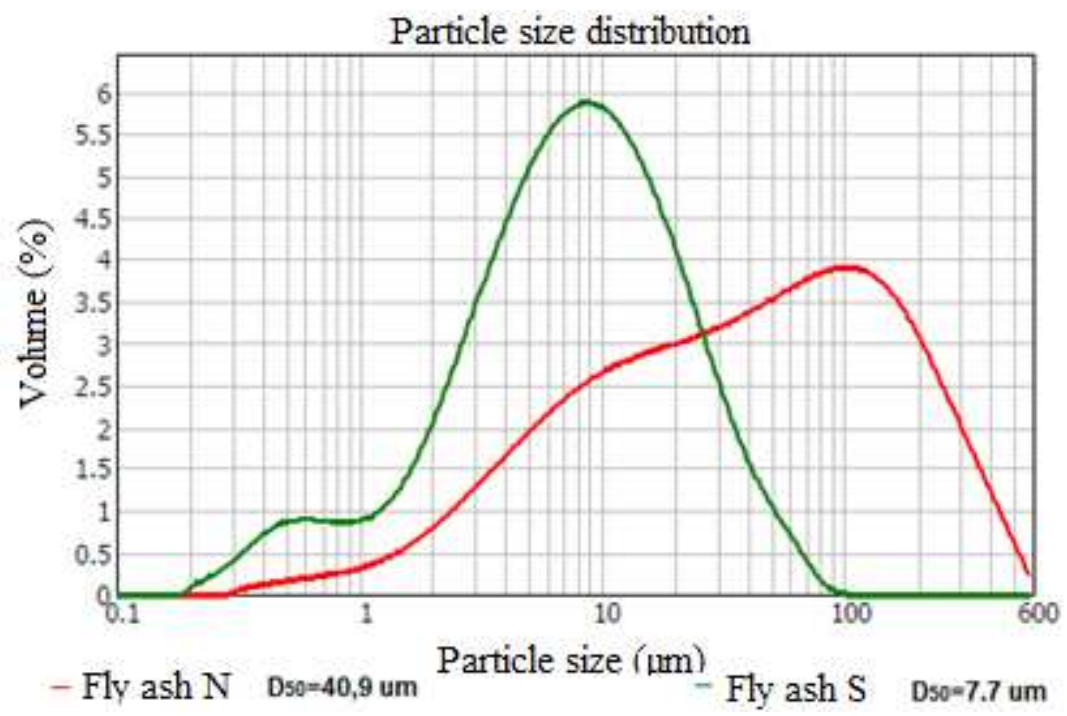

Fig. 1. Particle size distribution of silica fly ash category $\mathrm{N}$ and category $\mathrm{S}$.
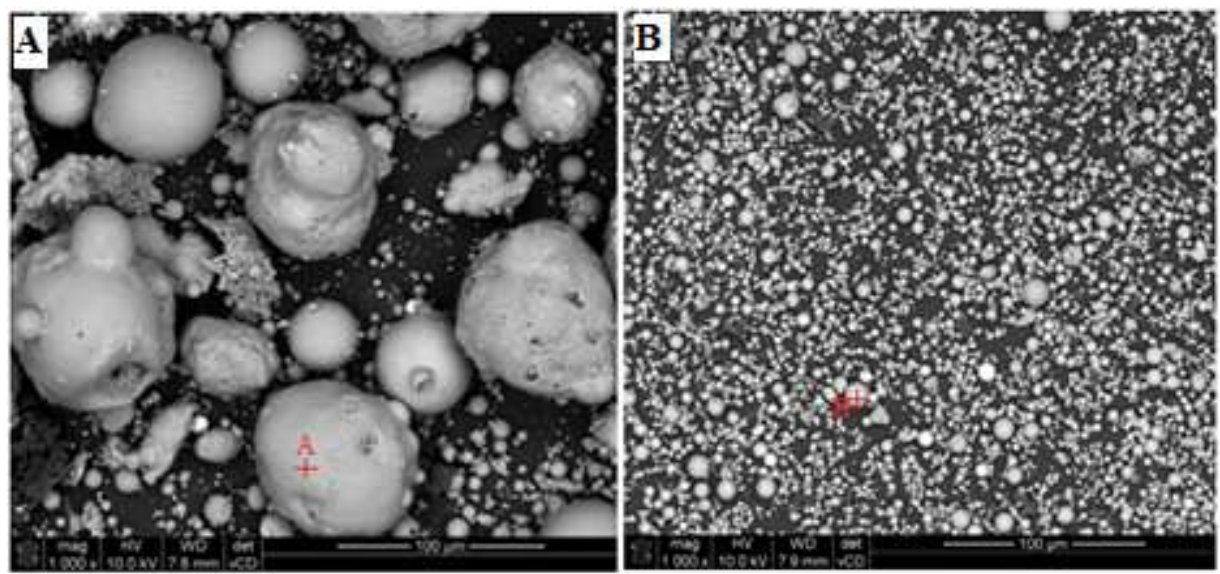

Fig. 2. SEM micrographs of silica fly ash. 1000x magnification. (A)- fly ash cat. N, (B)- fly ash cat. S 
In order to shape the rheological properties of concrete mixes with a low content of Portland clinker and a large proportion of active pozzolanic-hydraulic additives, a new generation liquefaction admixture based on polycarboxylic ether was used. This type of admixture allows the production of concrete mixes with low water content and good fluidity. Therefore, a reduced w/c ratio causes more effective cement hydration and increasing the density of concrete which leads to improvement of concrete strength.

Concrete mixes with low Portland clinker were designed; $70 \mathrm{~kg}, 100 \mathrm{~kg}, 120 \mathrm{~kg}$ of clinker in $1 \mathrm{~m}^{3}$ of concrete mix. These concrete mixtures were made of CEM III/B 42,4LLH/SR-NA cement and with the addition of $\mathrm{N}$ and $\mathrm{S}$ silica fly ash, as type II additive, with the aim of getting good rheological and long-term mechanical properties. Concrete was made at various w/c ratio with the addition of the new generation GleniumSky 430 superplasticizer. Portland cement CEM I 42.5 R was used in the control concrete, without mineral additives. Three reference concrete were designed, assuming 450, 360 and 280 $\mathrm{kg} / \mathrm{m}^{3}$ of cement in concrete mix, respectively for high strength concretes, reference concrete according to standards and concrete containing a minimum amount of cement, due to the exposure classes according to PN-EN 206-1 [18].

Concrete mixes were prepared from natural basalt, gravel and sand aggregates.

Concretes containing clinker in an amount of 120,100 and $70 \mathrm{~kg} / \mathrm{m}^{3}$ met the requirements for cement content and w/c ratio, according to requirements for exposure classes in standard PN-EN 206-1 [18].

The compositions of concrete mixes are presented in Table 3. The properties of designed concretes with a reduced content of Portland clinker was carried out in terms of compressive strength [18].

Table 3. Composition of concrete mixtures.

\begin{tabular}{|c|c|c|c|c|c|c|c|c|}
\hline Component & B120N & B120S & $\begin{array}{c}\text { B120 } \\
\text { CEM I }\end{array}$ & B100N & B100S & $\begin{array}{c}\text { B100 } \\
\text { CEM I }\end{array}$ & B70N & $\begin{array}{c}\text { B70 } \\
\text { CEM I }\end{array}$ \\
\hline CEM III/B 42,5L[kg/m³] & 400 & 400 & ----- & 332 & 332 & ----- & 233 & ----- \\
\hline Silica fly ash* $\left[\mathrm{kg} / \mathrm{m}^{3}\right]$ & $\mathrm{N}-125$ & $\mathrm{~S}-125$ & ----- & $\mathrm{N}-70$ & $S-70$ & ----- & $\mathrm{N}-118$ & ----- \\
\hline Cement $_{\mathrm{eq}}=\mathrm{C}+0,4 \mathrm{p}[\mathrm{N} 3]$ & 450 & 450 & ---- & 360 & 360 & ---- & 280 & ----- \\
\hline CEM I 42,5R $\quad\left[\mathrm{kg} / \mathrm{m}^{3}\right]$ & ----- & ----- & 450 & ----- & ----- & 360 & ----- & 280 \\
\hline$\left[\mathrm{kg} / \mathrm{m}^{3}\right]$ & 167 & 167 & 167 & 162 & 162 & 162 & 154 & 154 \\
\hline Sand $0-2 \mathrm{~mm}$ & 655 & 655 & 690 & 705 & 705 & 730 & 620 & 650 \\
\hline Basalt 2-8 mm $\quad\left[\mathrm{kg} / \mathrm{m}^{3}\right]$ & 550 & 550 & 580 & 590 & 590 & 610 & ----- & ----- \\
\hline Basalt $8-16 \mathrm{~mm} \quad\left[\mathrm{~kg} / \mathrm{m}^{3}\right]$ & 635 & 635 & 670 & 680 & 680 & 705 & ----- & ----- \\
\hline Gravel 2-8 $\mathrm{mm} \quad\left[\mathrm{kg} / \mathrm{m}^{3}\right]$ & ---- & ---- & ----- & ----- & ----- & ---- & 375 & 395 \\
\hline Gravel $8-16 \mathrm{~mm} \quad\left[\mathrm{~kg} / \mathrm{m}^{3}\right]$ & ----- & ---- & ---- & ---- & ---- & ----- & 415 & 435 \\
\hline Gravel $16-32 \mathrm{~mm}\left[\mathrm{~kg} / \mathrm{m}^{3}\right]$ & ---- & ---- & ---- & ---- & ---- & ---- & 470 & 495 \\
\hline $\mathrm{w} / \mathrm{s}(\mathrm{w} / \mathrm{c}+0,4 \mathrm{p})$ & 0,37 & 0,37 & 0,37 & 0,45 & 0,45 & 0,45 & 0,55 & 0,55 \\
\hline Portland clinker $\left[\mathrm{kg} / \mathrm{m}^{3}\right]$ & 120 & 120 & 430 & 100 & 100 & 340 & 70 & 270 \\
\hline \multicolumn{9}{|c|}{$\begin{array}{l}\text { B120/100/70/N/S- concrete mixtures containing } 120,100,70 \mathrm{~kg} / \mathrm{m}^{3} \text { of clinker made of CEM III/B } \\
42,5 \mathrm{~L} \text { cement, containing } 70 \% \text { slag and silica fly ash category N or S } \\
\text { B120/100/70/CEM I - reference concretes containing } 450,360,280 \mathrm{~kg} / \mathrm{m}^{3} \text { CEM I } 42,5 \mathrm{R} \text { cement } \\
\text { without additives } \\
* \mathbf{N} \text { - silica fly ash category } \mathrm{N} \text { and } \mathbf{S} \text { - silica fly ash category S according to PN-EN 450-1:2012 }\end{array}$} \\
\hline
\end{tabular}


The scope of testing concrete mixes included determination of: density, flow (consistency) and loss of consistency over time, air content. The consistency of concrete mixtures was tested using the cone fall method according to PN-EN 12350-2: 2011 [20].

The air content was tested using the pressure method according to PN-EN 12350-7: 2011 [21]. Compressive strengths of concretes after 2, 7, 28, 90 and 360 days were tested on $15 \mathrm{~cm}$ cubic samples, according to PN-EN 12390-3:20011 [22].

\section{Results}

The results contained in Table 4 shows that to ensure the assumed consistency and reduced water-cement ratio, the required amount of a superplasticizer is clearly smaller for concrete mixtures with a low Portland clinker, compared to the reference mixtures of CEM I 42.5R. This relate should be linked with the use of high-quality silica fly ash, which shapes better the rheological properties of the concrete mix.

The air content in all concrete mixes was similar and amounted $1.8 \%$ to $2.0 \%$, i.e. below the limit of $2 \%$ for a properly prepared concrete mix (Tab.4).

Concrete mixes containing a very low amount of Portland clinker $70-120 \mathrm{~kg} / \mathrm{m}^{3}$ compared to reference mixtures of CEM I cement also show greater stability in maintaining a constant consistency over time, maintaining the assumed consistency class of the S4/S3 mix for up to $60 \mathrm{~min}$ (Tab.4).

Table 4. Properties of concrete mixes.

\begin{tabular}{|c|c|c|c|c|c|c|c|c|}
\hline \multirow[b]{2}{*}{ Properties } & \multicolumn{8}{|c|}{ Description of concrete } \\
\hline & $120 N$ & $120 S$ & $\begin{array}{c}120 \\
\text { CEM I }\end{array}$ & $100 N$ & $100 \mathrm{~S}$ & $\begin{array}{c}100 \\
\text { CEM I }\end{array}$ & $70 N$ & $\begin{array}{c}70 \\
\text { CEM I }\end{array}$ \\
\hline Superplasticizer PCE & 0.80 & 0.65 & 1.65 & 0.40 & 0.40 & 0.80 & 0.80 & 1.20 \\
\hline Initial consistency & 160 & 150 & 150 & 170 & 170 & 180 & 165 & 130 \\
\hline Consistency after $30 \mathrm{~min} . \quad[\mathrm{mm}]$ & 160 & 150 & 150 & 160 & 170 & 170 & 160 & 130 \\
\hline Consistency after $60 \mathrm{~min} . \quad[\mathrm{mm}]$ & 140 & 140 & 130 & 160 & 160 & 150 & 150 & 100 \\
\hline Air content $\quad[\%]$ & 2.0 & 2.0 & 2.0 & 1.8 & 2.0 & 1.8 & 1.8 & 2.0 \\
\hline$\left[\mathrm{kg} / \mathrm{dm}^{3}\right]$ & 2.49 & 2.49 & 2.49 & 2.49 & 2.48 & 2.48 & 2.39 & 2.38 \\
\hline
\end{tabular}

The results of compressive strength of low Portland clinker concrete $70-120 \mathrm{~kg} / \mathrm{m}^{3}$ of concrete mix are compiled in Table 5 and Figure 3 . The strength of concrete $120 \mathrm{~N} / \mathrm{S}$ with a Portland clinker content of $120 \mathrm{~kg} / \mathrm{m}^{3}$ after 2 days of hardening is clearly lower in comparison to the reference concrete made of CEM I 42.5R cement. After further hardening periods very large increases in concrete strength are observed. Already after 7 days the $120 \mathrm{~N} / \mathrm{S}$ with a Portland clinker content of $120 \mathrm{~kg} / \mathrm{m}^{3}$ concrete compressive strength is $55 \mathrm{MPa}$ and achieves the strength of reference concrete containing $450 \mathrm{~kg}$ of cement in $1 \mathrm{~m}^{3}$ of concrete mix. After 28 days the relative strength of $120 \mathrm{~N} / \mathrm{S}$ concrete is about $140 \%$ of the reference concrete strength (Fig. 4). Compressive strength of concrete $120 \mathrm{~N} / \mathrm{S}$ achieves $89 / 92 \mathrm{MPa}$ after 28 days corresponds to the strength class of concrete C60/75 [18]. 120CEM I reference concrete meets the requirements for strength class C50/60. Large increases in strength for $120 \mathrm{~N} / \mathrm{S}$ concrete are also observed in later hardening periods. The strength of concrete $120 \mathrm{~S}$ exceeds $100 \mathrm{MPa}$ after 90 days (Tab.5, Fig.3).

The increase dynamics of strength $120 \mathrm{~N} / \mathrm{S}$ concrete with the 0.37 water-cement ratio were confirmed for the $100 \mathrm{~N} / \mathrm{S}$ concrete series containing $100 \mathrm{~kg}$ of Portland clinker. At a $\mathrm{w} / \mathrm{c}=0.45,100 \mathrm{~N} / \mathrm{S}$ concretes show very low strength after 2 days of hardening and large increases after further periods. Standard strength after 28 days of $100 \mathrm{~N} / \mathrm{S}$ concrete reaches $70 \mathrm{MPa}$, clearly exceeding the strength of reference concrete containing $360 \mathrm{~kg}$ of Portland 
cement CEM I 42.5R (Tab. 5, Fig. 3, Fig. 5). The concrete 100N/S meet the requirements for strength class C50/60 after 28 days (Tab.5).

The dynamics of hardening of $70 \mathrm{~N}$ concrete containing $70 \mathrm{~kg}$ of Portland clinker and the addition of category $\mathrm{N}$ fly ash confirms the relations discussed for $120 \mathrm{~N} / \mathrm{S}$ and $100 \mathrm{~N} / \mathrm{S}$ concretes. At a w/c=0.55, the early strength of $70 \mathrm{~N}$ concrete after 2 days is only $10 \mathrm{MPa}$, with a large increase in strength after further hardening periods (Tab. 5, Fig. 3). The relative strength of $70 \mathrm{~N}$ concrete after 28 days of hardening is $127 \%$ of reference concrete strength 70CEM I containing $280 \mathrm{~kg}$ of CEM I 42.5R (Fig. 6). The absolute strength of $70 \mathrm{~N}$ concrete after 28 days is $60 \mathrm{MPa}$ and meets the requirements for the strength class of structural concrete C40/50 (Tab.5, Fig.3).

Table 5. Compresive strength of concretes.

\begin{tabular}{|l|c|c|c|c|c|c|}
\hline \multirow{2}{*}{$\begin{array}{c}\text { Description of } \\
\text { concrete }\end{array}$} & \multicolumn{5}{|c|}{ Compressive strength [MPa] } & \multirow{2}{*}{$\begin{array}{c}\text { Concrete } \\
\text { strength class [18] }\end{array}$} \\
\cline { 2 - 7 } & 2 days & $\mathbf{7}$ days & $\mathbf{2 8}$ days & $\mathbf{9 0}$ days & $\mathbf{3 6 0}$ days & \multirow{2}{*}{ C50/60 } \\
\hline $120 \mathrm{~N}$ & 20.6 & 55.1 & 92.0 & 96.2 & 112.3 & \\
\hline $120 \mathrm{~S}$ & 18.1 & 55.3 & 89.0 & 104.4 & 110.6 & \\
\hline $120 \mathrm{CEM}$ I & 39.5 & 55.8 & 64.3 & 71.2 & 79.6 & \\
\hline \hline $100 \mathrm{~N}$ & 12.4 & 35.3 & 68.9 & 82.4 & 87.9 & \multirow{2}{*}{$\mathrm{C} 40 / 50$} \\
\hline $100 \mathrm{~S}$ & 12.6 & 33.7 & 70.9 & 82.3 & 90.0 & \\
\hline $100 \mathrm{CEM}$ I & 31.3 & 50.3 & 60.3 & 66.3 & 73.1 & \\
\hline \hline $70 \mathrm{~N}$ & 10.4 & 30.2 & 59.6 & 72.1 & 81.7 & \multirow{2}{*}{$\mathrm{C} 25 / 30$} \\
\hline 70 CEM I & 20.8 & 34.9 & 46.8 & 59.0 & 71.0 & \\
\hline
\end{tabular}

\section{Concretes}

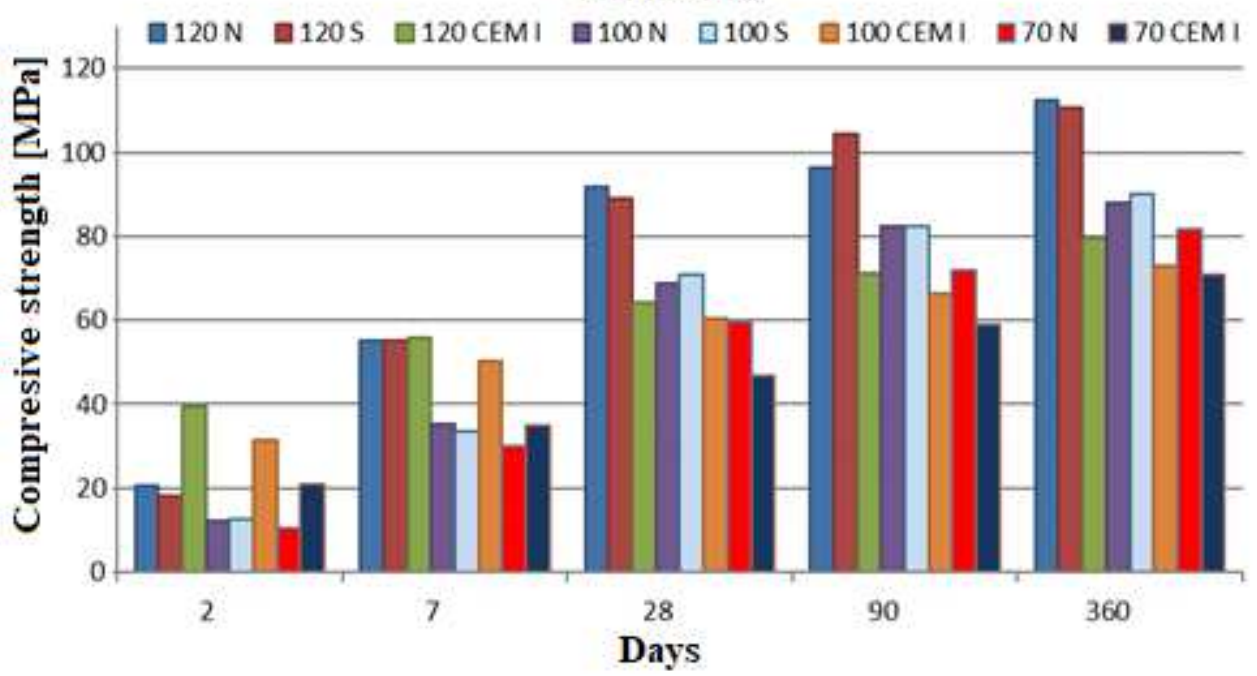

Fig. 3. Compressive strength of concretes 


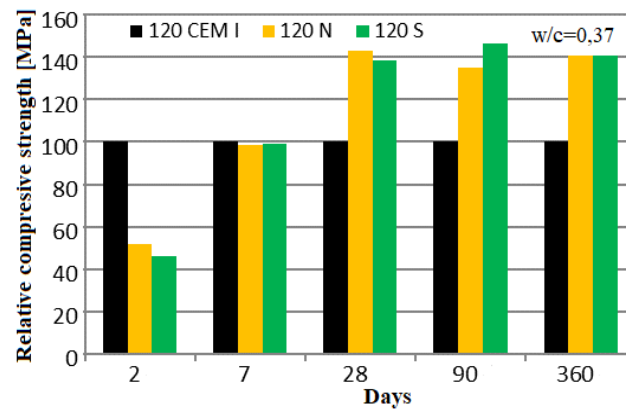

Fig. 4. Relative compressive strength of $120 \mathrm{~N} / \mathrm{S}$ concrete containing $120 \mathrm{~kg}$ of Portland clinker in $1 \mathrm{~m}^{3}$ of concrete.

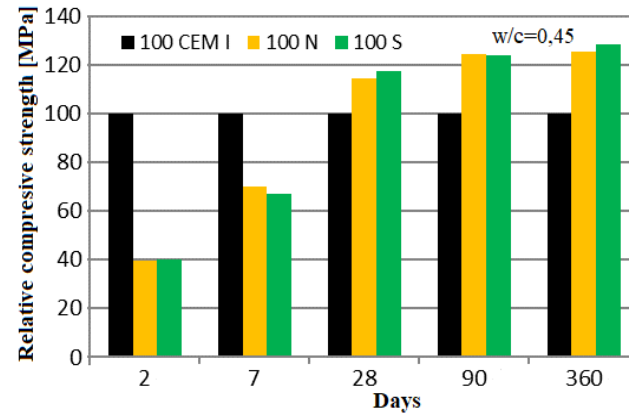

Fig. 5. Relative compressive strength of $100 \mathrm{~N} / \mathrm{S}$ concrete containing $120 \mathrm{~kg}$ of Portland clinker in $1 \mathrm{~m}^{3}$ of concrete.

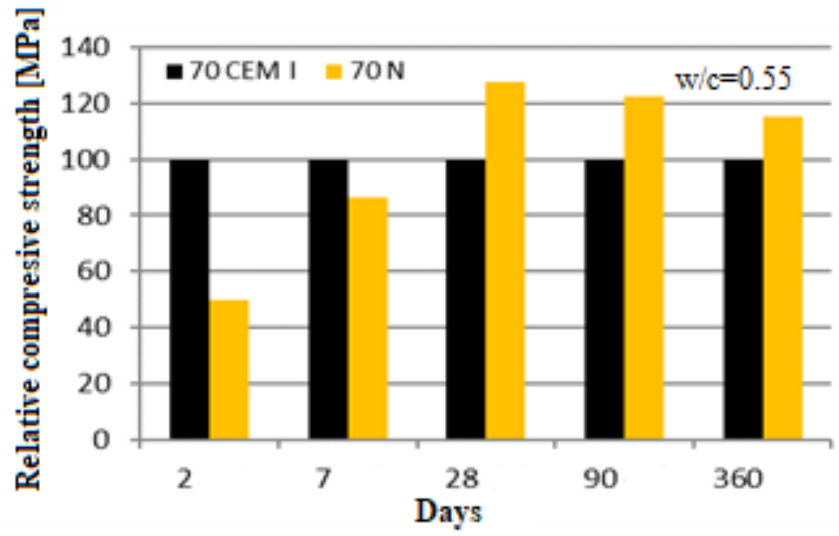

Fig. 6. Relative compressive strength of $70 \mathrm{~N}$ concrete containing $70 \mathrm{~kg}$ Portland clinker in $1 \mathrm{~m}^{3}$ of concrete.

The use of fly ash and granulated slag as substitute of Portland clinker (cement) in concrete has an impact on reducing $\mathrm{CO}_{2}$ emissions. The $\mathrm{CO}_{2}$ reduction effect can be calculated per unit of product, i.e. cement at concrete and cement producers. Replacing $1 \%$ of clinker in cement with ash or slag can reduce $\mathrm{CO}_{2}$ emissions by $9.1 \mathrm{~kg} / \mathrm{t}$ of cement. Accordingly, the transition from the production of CEM III/A cement containing $50 \%$ slag to the production of CEM III/B cement containing $70 \%$ slag gives the effect of reducing $\mathrm{CO}_{2}$ emissions to $182 \mathrm{~kg} / \mathrm{t}$ of cement. This is the basic environmental effect of the increased use of slag and ash in multi-component cement technology. This effect can be more increased if cement used in a concrete has a low content of clinker and additionally the fly ash is used as a type II additive in concrete. The scale of effects resulting from the increased content of non-clinker components in concrete is presented in Fig. 7, where the amount of $\mathrm{CO}_{2}$ reduction is shown for concrete with a large addition of mechanically activated fly ash and slag. Compared to reference concrete made of CEM I, $\mathrm{CO}_{2}$ emissions are on average 3 times lower. 


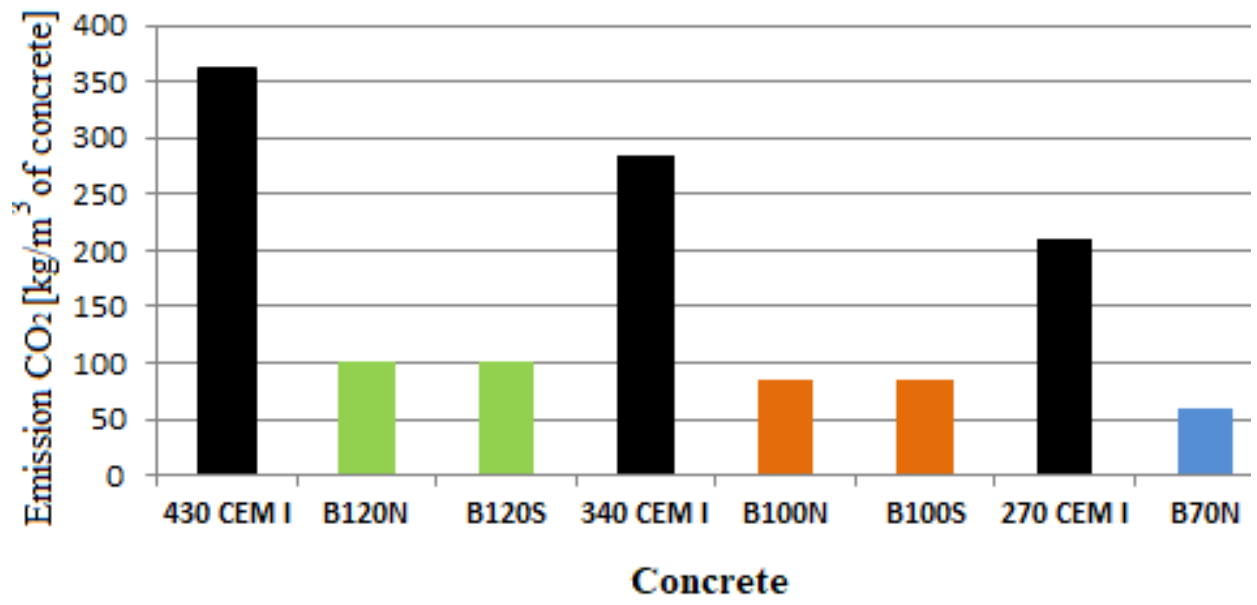

Fig. 7. Reduction of $\mathrm{CO}_{2}$ from production of concrete with a low content of Portland clinker.

Data used in the calculation:

1. $850 \mathrm{~kg} \mathrm{CO}_{2} / \mathrm{t}$ of clinker - the amount of $\mathrm{CO}_{2}$ emission in the dry production process of 1 ton of clinker from natural raw materials.

2. $93 \%$ - the amount of clinker content in CEM I as reference cement;

$3.70 \%$ - the amount of slag content in cement CEM III/B 42.5L.

\section{Discussion}

Granulated blast furnace slag and high-quality silica fly ash are valuable components of concrete with a low content of cement clinker.

An important component of concrete with a low content of cement clinker is suitable quality fly ash. Good quality fly ash reduces water content and improves consistency, ensuring good workability with a reduced water-cement ratio in the concrete mix.

In concretes with a low w/c ratio (below 0.4 ), fly ash of the $\mathrm{S}$ category is particularly useful. The use of this type of fly ash allows to significantly improve rheological properties (reduction of the water requirement of the binder in concrete) and strength in longer hardening periods (over 28 days).

By using CEM III/B metallurgical cement with a specific surface area of approx. $5000 \mathrm{~cm}^{2} / \mathrm{g}$, silica fly ash of categories $\mathrm{N}$ and $\mathrm{S}$ containing up to $5 \%$ roasting loss (category A) and the latest generation superplasticizers, we can obtain fully useful structural concrete in the strength class from $\mathrm{C} 50 / 60$ (clinker content $120 \mathrm{in}^{3}$ of concrete mix), through class $\mathrm{C} 40 / 50$ (clinker content $100 \mathrm{~kg} / \mathrm{m}^{3}$ ) to class C $25 / 30$ (clinker content $70 \mathrm{~kg} / \mathrm{m}^{3}$ ).

The hardening dynamics of concretes containing $120 \mathrm{~kg} / \mathrm{m}^{3}$ of Portland clinker confirms the possibility of designing high-strength concretes using the effect of mechanical activation of pozzolanic-hydraulic additives introduced into the concrete mix.

The production and use of concrete with a low content of cement clinker in construction allows achieving significant ecological effects: $\mathrm{CO}_{2}$ emission reduced by almost three times compared to concrete made of CEM I Portland cement, management of heavy secondary raw materials from the energy and metallurgy industries and reduction of the surface area for landfills. 


\section{References}

1. R. Siddique, Waste Materials and By-Products in Concrete. (Engineering Materials, Indie, 2008)

2. S. Chłądzyński, A. Garbacik, Cementy wieloskładnikowe w budownictwie (The Polish Cement, Kraków, 2008) (in Polish)

3. A. M. Neville, Properties of Concrete (The Polish Cement, wyd. 4, Kraków, 2012)

4. Z. Giergiczny, Cement and Concrete Res. 124 (2019)

5. R. N. Swamy, Design for durability and strength through the use of fly ash and slag in concrete (American Concrete Institute SP-178. 171, 1997)

6. B. Pedersen, Durability aspects of fly ash and slag in concrete (Report of Norvegian Public Roads Administartion, 149, 2012)

7. Z. Giergiczny, Popiót lotny w sktadzie cementu i betonu (Monografia. Wydawnictwo Politechniki Śląskiej, Gliwice, 2013) (in Polish)

8. G. J. McCarthy, F. P. Glasser, D. M. Roy, III.MRS, 86, 139-158 (1987)

9. Oddziaływanie przemysłu cementowego (www.polskicement.pl, 2016) (in Polish)

10. Badania kontrolne OSIMB jakości i zawartości składników prowadzone na rzecz producentów cementów hutniczych i popiołowo żużlowych (2015-2016) (in Polish)

11. T. Baran, P. Francuz, Cement Lime Concrete. 6, 375 (2015)

12. M. Oner, K. Erdogu, A. Gunulu, Cem. Concr. Res. 33, 463-469 (2003)

13. S. Kumar, A. Bandopadhyay, V. Rajinikanth, T. C. Alex, R. Kumar, J. Mater. Sci. 39, 3449-3452 (2004)

14. M. Behim, P. Beddar, Slovak J. Civil Eng. XXI, 2, 7-14 (2013)

15. D. Lutze, W. Berg, Popiót lotny w betonie, (Polska Unia UPS, Warszawa, 2010) (in Polish)

16. W. Kurdowski, J. Szwabowski, J. Śliwiński, Kompozyt betonowy z matryca cementowa o ultra wysokich właściwościach mechanicznych (Grant badawczy R04 002 02, 1998) (in Polish)

17. M. Alkaysi, S. El-Tawil, Z. Liu, W. Hansen, Cem. Concr. Compos. 66, 47-56 (2016)

18. PN-EN 206-1:2014 Beton. Wymagania, właściwości, produkcja i zgodność. (in Polish)

19. PN-EN 196-2:2013-11 Metody badania cementu. Część 2: Analiza chemiczna cementu. (in Polish)

20. PN-EN 12350-2:2011 Badania mieszanki betonowej - Część 2: Badanie konsystencji metodą opadu stożka. (in Polish)

21. PN-EN 12350-7:2011 Badania mieszanki betonowej - Część 7: Badanie zawartości powietrza - Metody ciśnieniowe. (in Polish)

22. PN-EN 12390-3:2011 Badania betonu - Część 3: Wytrzymałość na ściskanie próbek do badań. (in Polish) 